\title{
UPAYA MENINGKATKAN HASIL BELAJAR SISWA PADA MATA PELAJARAN PENDIDIKAN KEWARGANEGARAAN (PKN) MELALUI METODE INQUIRI DI KELAS III SD NEGERI 168060 KOTA TEBING TINGGI
}

\author{
Merlin Simangunsong \\ Surel: merlinsimangunsong14@gmail.com
}

\begin{abstract}
This Classroom Action Research aims to improve PKn learning outcomes of class III students by using the Inquiri Method The study was conducted at the 168060 Public Elementary School in Tebing Tinggi City. With the subject of the action of 1 teacher and the recipient of the action are class III students totaling 35 people. This research was conducted in 2 cycles, each cycle using procedures, namely planning, implementing actions, observing and reflecting. The hypothesis in PTK is: Through the application of the Cooperative learning model with the inquiry method, the learning achievements of class III students in PKn subjects can be improved. The evaluation results prove that after the first cycle of action the learning outcomes of new students reach $54.28 \%$ with an average of 64.62 while the second cycle reaches $85.71 \%$ with an average of 75.71 while the percentage of student activity in the first cycle reaches $50,86 \%$, overall the second cycle increased by $43.75 \%$ with attainment of $94.61 \%$.
\end{abstract}

Keywords: Inquri Method, Learning Outcomes, Student Activity Increases.

\begin{abstract}
ABSTRAK
Penelitian Tindakan Kelas ini bertujuan meningkatkan hasil belajar PKn siswa kelas III dengan menggunakan Menggunakan Metode Inquiri Penelitian dilaksanakan di Sekolah Dasar Negeri 168060 Kota Tebing Tinggi. Dengan subjek pelaku tindakan 1 guru dan subjek penerima tindakan adalah siswa kelas III yang berjumlah 35 orang. Penelitian ini dilaksanakan sebanyak 2 siklus, setiap siklus menggunakan prosedur yaitu perencanaan, pelaksanaan tindakan, pengamatan dan refleksi. Hipotesis dalam PTK ini adalah : Melalui penerapan model pembelajaran Kooperatif dengan metode inquiri prestasi belajar siswa kelas III dalam mata pelajaran PKn dapat ditingkatkan. Hasil evaluasi membuktikan, setelah dilakukan tindakan siklus pertama hasil belajar siswa baru mencapai 54,28\% dengan rata-rata 64,62 sedangkan siklus yang kedua mencapai $85,71 \%$ dengan rata-rata 75,71 sedangkan prosentase keaktifan siswa pada siklus pertama mencapai $50,86 \%$, secara keseluruhan siklus kedua terjadi peningkatan $43,75 \%$ dengan pencapaian $94,61 \%$.
\end{abstract}

Kata Kunci: Metode Inquri, Hasil Belajar, Aktivitas Siswa Meningkat.

\section{PENDAHULUAN}

Pendidikan

berdasarkan Pancasila

untuk meningkatkan

Nasional

bertujuan

kualitas

manusia Indonesia, yaitu manusia yang beriman dan bertaqwa terhadap
Tuhan Yang Maha Esa, berbudi pekerti luhur, berkepribadian, berdisiplin, bekerja keras, tangguh, bertanggungjawab, mandiri, cerdas dan terampil serta sehat jasmani dan rohani. Pendidikan nasional juga 
harus mampu menumbuhkan dan memperdalam rasa cinta pada tanah air, mempertebal semangat kebangsaan dan rasa kesetiakawanan sosial. Dalam dunia pendidikan kita sering mendengar ungkapan yang cukup sederhana yaitu "mendidik anak pada masa kini berarti menyiapkan orang dewasa di masa mendatang". Pendidik haru:s bisa menyiapkan anak didik menjadi orang dewasa yang mandiri, mampu menggunakan dan mengembangkan sendiri kemampuan (pengetahuan dan keterampilan) yang telah dimilikinya, dan mempunyai sikap yang sesuai dengan norma-norma yang berlaku di masyarakat.

Sejalan dengan hal tersebut di atas, dikembangkan iklim belajar mengajar yang dapat menumbuhkan rasa percaya diri serta sikap dan perilaku yang inovatif dan kreatif. Dengan demikian pendidikan nasional akan mampu mewujudkan manusia manusia pembangunan yang dapat membangun dirinya sendiri serta bersama-sama bertanggung jawab atas utuhnya Negara Kesatuan Republik Indonesia.

Pendidikan Pancasila dan Kewarganegaraan yang sesuai dengan isi Kurikulum 2004 adalah pendidikan tentang nilai-nilai yang sasarannya bukan semata-mata pengalihan pengetahuan melainkan lebih ditekankan pada pembentukan sikap. Dengan demikian mata pelajaran PKn meliputi ranah kognitif, afektif dan psikomotor, yang lebih menitikberatkan pada ranah afektif.
Kepribadian siswa pada hakikatnya dipengaruhi oleh ranah kognitif, apektif dan psikomotor. Ketiga ranah tersebut menyatu dan sulit dipisahkan satu dengan yang lainnya, sehingga membentuk kepribadian unik setiap manusia. Dalam menyajikan pelajaran, guru harus berupaya mengembangkan ketiga ranah tersebut agar berkembang sesuai dengan yang diharapkan. Dalam pelaksanaan Pelajaran terdapat perbedaan tergantung dari ranah mana yang mendapat penekanan, sementara dalam Pelajaran PKn, hasil akhir yang menjadi tujuan adalah pengembangan ranah apektif yang sesuai dengan nilai dan norma yang berlaku dan berkembang dalam tatanan kehidupan manusia Indonesia.

Dalam proses Pelajaran PKn, guru belum semuanya melaksanakan pendekatan siswa aktif, dan peranan guru sebagai dinamisator belajar siswa belum diterapkan, namun guru masih dominan menggunakan metode ceramah dan tanya jawab. Dalam penyampaian materi pelajaran guru masih menggunakan buku-buku sumber dan buku pelengkap sebagai sumber belajar, dan dalam penyampaian bahan ajar kepada siswa belum digunakan media belajar yang lain.

Selama ini proses Pelajaran PKn di Kelas III kebanyakan masih mengunakan metode ceramah dimana guru memberikan pengetahuan kepada siswa yang duduk, diam, dengar, catat dan hafal. 
Sehingga kegiatan belajar mengajar menjadi monoton dan kurang menarik perhatian siswa. Kondisi seperti itu tidak akan meningkatkan kemampuan siswa dalam memahami mata pelajaran PKn. Akibatnya nilai akhir yang dicapai siswa tidak seperti yang diharapkan. Di Kelas III selama ini siswanya masih kurang aktif dalam hal bertanya dan menjawab, hasil yang dicapai siswa Kelas III sangat jauh dari memuaskan. Berdasarkan analisis situasi/latar belakang diatas maka penulis berkeinginan untuk memperbaiki/ mengadakan inovasi Pelajaran. Pelajaran PKn sebenarnya mempunyai peran yang sangat penting. Mata pelajaran PKn diharapkan akan mampu membentuk siswa yang ideal memiliki mental yang kuat, sehingga dapat mengatasi permasalahan yang akan dihadapi.

Dari permasalahan diatas, sudah selayaknya dalam pengajaran PKn dilakukan suatu inovasi. Jika dalam Pelajaran yang terjadi sebagian besar dilakukan oleh masing-masing siswa, maka dalam penelitian ini akan diupayakan peningkatan pemahaman siswa melalui metode inkuiri. Metode inkuiri merupakan suatu pendekatan pengajaran yang efektif dalam pencapaian tujuan pendidikan. Diharapkan melalui metode inkuiri dapat meningkatkan pemahaman siswa, meningkatkan semangat kebersamaan serta saling membantu dalam menguasai materi PKn. Sehingga siswa dapat meningkatkan pemahaman yang optimal terhadap mata pelajaran PKn.

Permasalahan dalam penelitian ini adalah tindakan apa yang dilakukan guru untuk meningkatkan hasil belajar siswa pada mata pelajaran PKn. banyak faktor yang mungkin bisa menjadi penyebab terjadi permasalahan tersebut diatas. Dengan merefleksi bersama antar guru, teridentifikasi akar permasalahan diduga penyebab masalah tersebut, yaitu penggunaan strategi Pelajaran yang dilakukan guru PKn masih konvensional, dominasi guru dalam kelas dominan sehingga menyebabkan keadaan kelas yang monoton serta membosankan.

Berdasarkan latar belakang masalah di atas, maka tujuan penelitian ini adalah:

a. Meningkatkan kemampuan hasil belajar PKn melalui metode inkuiri pada siswa Kelas III SD Negeri 168060 kota Tebing Tinggi.

b. Meningkatkan kualitas proses Pelajaran PKn melalui metode inkuiri pada siswa Kelas III SD Negeri 168060 kota Tebing Tinggi.

\section{METODE PENELITIAN}

Penelitian ini dilaksanakan di SD Negeri 168060 Jl. Gunung Arjuna, Kecamatan Rambutan Kota Tebing Tinggi waktu penelitian dilakukan di semester satu mulai.

Subjek penelitian ini adalah siswa kelas III yang berjumlah 35 orang, laki-laki 18 orang dan perempuan 17 orang siswa SD Negeri 168060 kecamatan Rambutan Kota Tebing Tinggi. 
Teknik pengumpulan data yang digunakan dalam penelitian ini adalah melalui pengamatan dengan mengisi lembar observasi, angket dan pemberian tes hasil belajar.

a. Untuk mengetahui aktivitas siswa selama proses pembelajaran berlangsung, digunakan lembar observasi yang meliputi aktivitas siswa dan aktivitas guru pada saat guru menyampaikan kegiatan pembelajaran.

b. Tes hasil belajar digunakan untuk mengetahui peningkatan hasil belajar setelah berlangsung proses pembelajaran. Tes yang dimaksud adalah tes hasil belajar yang menyangkut ranah kognitif yang diadakan pada akhir siklus.

Teknik analisis data yang digunakan adalah untuk data aktivitas siswa diolah secara kuantitatif dengan menghitung persentasenya, dengan menggunakan rumus yang dikemukakan oleh Anas Sudijono (1997) sebagai berikut :

Keterangan :

$\mathrm{P}=$ Presentase

$\mathrm{F}=$ Frekuensi aktivitas belajar siswa

$\mathrm{N}=$ Jumlah siswa seluruhnya

Selanjutnya berdasarkan prosentase yang diperoleh, maka criteria aktivitas siswa dan guru menurut Dimyati dan Mudjiono (2006:125) sebagai berikut :

$\begin{array}{ccl}1-25 \% & : & \text { Sedikit sekali } \\ 26-50 \% & : & \text { Sedikit } \\ 51-75 \% & : & \text { Banyak } \\ 76-99 \% & : & \text { Banyak sekali }\end{array}$

Untuk data hasil belajar dianalisis dengan melihat ketuntasan hasil belajar siswa secara individual. Dikatakan seorang siswa tuntas belajar apabila mencapai nilai ketuntasan/tingkat penguasaan minimal yang ideal yaitu $75 \%$ (Depdiknas, 2004). Untuk SD Negeri 168060 kota Tebing Tinggi Nilai Kriteria Ketuntasan Minimal (KKM) untuk pelajaran PKn yang telah ditetapkan adalah 70\%. Tingkat penguasaan hasil belajar dapat dihitung dengan menggunakan rumus sebagai berikut :

Dimana :

$\mathrm{NI}=$ Ketuntasan Belajar Individu

$\mathrm{T}=$ Skor Yang Diperoleh Siswa

$\mathrm{SM}=$ Skor Maksimum Tes

\section{HASIL PENELITIAN DAN PEMBAHASAN}

Pada siklus I, secara garis besar kegiatan belajar mengajar dengan metode pembelajaran inkuiri dilaksanakan belum dengan baik dan masih ke dalam kategori kurang.Aktivitas siswa yang dominan adalah Siswa dan guru bersama-sama membuat kesimpulan (58,57\%).Aktivitas lain yang presentasinya cukup besar adalah siswa dan guru bersama-sama membuat kesimpulan (71,24\%). Kemampuan siswa menjawab pertanyaan, keantusiasan siswa mengikuti pelajaran dan lain-lain masih dinilai kurang. Pada saat guru menjelaskan keadaan murid berbedabeda ada yang memperhatikan guru, ada yang bermain, ada yang ngobrol 
Merlin SImangunsong : Upaya Meningkatkan Hasil Belajar ...

dengan teman, ada yang mengerjakan tugas.

Kemudian siswa dan guru bersama-sama mengevaluasi kegiatan, selain itu garu juga memberikan penguatan, dorongan serta penghargaan bagi kelompok. Beberapa aspek yang mendapat nilai kurang baik di atas merupakan suatu kelemahan yang terjadi pada siklus I dan akan dijadikan bahan kajian untuk refleksi dan revisi yang akan dilakukan pada siklus II. di atas dapat dijelaskan bahwa dengan menerapkan metode pembelajaran inkuiri pada materi "Peran Indonesia di Dunia Internasional" diperoleh nilai rata-rata ulangan harian siswa adalah 64,62 dan ketuntasan belajar mencapai $57,57 \%$ atau ada 19 siswa dari 35 siswa sudah tuntas belajar. Hasil tersebut menunjukkan bahwa pada siklus pertama secara klasikal siswa belum tuntas belajar, karena siswa yang memperoleh nilai $\geq 70$ hanya sebesar 54,28 \% lebih kecil dari persentase ketuntasan yang dikehendaki yaitu sebesar $75 \%$. Hal ini disebabkan karena siswa masih bingung dalam memahami konsepkonsep materi pembelajaran.

Pada siklus II, secara garis besar kegiatan belajar mengajar dengan metode pembelajaran inkuiri dilaksanakan terjadi peningkatan. Aktivitas siswa yang dominan adalah Siswa menjawab pertanyaan $(82,85 \%)$. Aktivitas lain yang presentasinya cukup besar adalah Siswa menerima dan mengerjakan LKS, Mengerjakan tes evaluasi $(94,28 \%)$ Siswa dalam pembelajaran

yang menerapkan metode inkuiri secara berkelompok, mereka tampak aktif berdiskusi mengerjakan tugas. di atas dapat dijelaskan bahwa dengan menerapkan metode pembelajaran inkuiri pada pelajaran PKn diperoleh nilai rata-rata ulangan harian siswa adalah 75.71 dan ketuntasan belajar mencapai 85,71\% atau ada 30 siswa dari 33 siswa sudah tuntas belajar. Hasil tersebut menunjukkan bahwa pada siklus ketiga secara klasikal siswa sudah tuntas belajar, karena siswa yang memperoleh nilai $\geq 70$ sebesar 90.90 $\%$. Nilai tersebut sudah melebihi dari persentase ketuntasan yang dikehendaki yaitu sebesar $75 \%$.

\section{Pembahasan}

Model pembelajaran kooperatif dengan mengunakan metode inkuiri ini merupakan suatu cara yang pada dasarnya mampu mendorong terlaksananya aktivitas kelompok guna memantapkan cara berpikir siswa secara individu maupun kelompok dalam pemahaman konsep dan menyelesaikan soal-soal yang diberikan guru. Keunggulan lain seperti berinteraksi dan mengemukakan pendapat juga terasa. Dalam hal ini kerangka kerja siswa dibentuk dalam suatu kerjasama yang melibatkan kemampuan bekerja / belajar bersama untuk menemukan konsep dan memecahkan masalah.

Penerapan model pembelajaran kooperatif dengan mengunakan metode inkuiri yang 
telah dilaksanakan juga dapat meningkatkan hasil belajar siswa.

Peningkatan hasil belajar siswa ini disebabkan oleh karena model pembelajaran kooperatif dengan mengunakan metode inkuiri yang dasarkan pada pandangan konstruktivis, siswa harus menemukan dan mengkonstruksi sendiri pengetahuannya. Hal ini dapat dilakukan dengan berdiskusi, berbagi pengalaman dan mengerjakan tugas-tugas secara kontinu dan bertahap.

Dalam pembelajaran dengan model kooperatif dengan mengunkan metode inkuiri ini siswa diarahkan menemukan konsep dengan bantuan Lembar Kerja Siswa (LKS) melalui kegiatan-kegiatan penyelidikan. Kegiatan penyelidikan dimulai dari pemberian masalah kepada siswa yang berhubungan dengan kehidupan sehari-hari, sehingga siswa termotivasi untuk memahaminya lebih jauh dan memacu siswa untuk berfikir kritis untuk memecahkan masalah tersebut. Penemuan konsep dan prinsip yang dilakukan siswa melibatkan proses mental dalam mencari hubungan-hubungan, membuat dugaan sehingga pengetahuan yang didapat sangat kukuh dan mendalam karena siswa sendiri yang menemukan konsepnya.

Proses penemuan konsep dilakukan secara berkelompok, siswa memiliki tanggung jawab secara individu dan kelompok dan memiliki kesempatan yang sama untuk berhasil. Siswa yang memiliki kemampuan pembelajaran PKn lebih tinggi dapat membantu siswa (kelompoknya) yang kemampuannya lebih rendah dalam belajar PKn

\section{SIMPULAN}

Setelah dilakukan penelitian tindakan kelas, maka berdasarkan hasil observasi dan hasil refleksi dapat disimpulkan bahwa: Pembelajaran dengan menggunakan model kooperatif dengan mengunakan metode inkuiri dapat meningkatkan aktivitas belajar PKn siswa Kelas III SD Negeri 168060 kota Tebing Tinggi. Pembelajaran dengan menggunakan model kooperatif dengan mengunakan metode inkuiri dapat meningkatkan hasil belajar PKn siswa Kelas III SD Negeri 168060 kota Tebing Tinggi. Dengan penerapan model pembelajaran kooperatif dengan mengunakan metode inkuiri dapat menumbuhkan dan memberi peluang kepada siswa dalam mengembangkan dan melatih sikap serta ketrampilan sosial yang bermanfaat bagi kehidupan dan masyarakat.

Hasil temuan penelitian ini memberikan masukan kepada peneliti, bahwa untuk meningkat efektivitas pembelajaran PKn perlu menggunakan model pembelajaran ini. PKn merupakan pelajaran yang dianggap membosankan bagi kebanyakan siswa, karena terpusat pada guru oleh karena itu guru perlu menciptakan suasana belajar menyenangkan, adanya kerjasama di antara siswa, sehingga siswa termotivasi dalam belajar. 
Merlin SImangunsong : Upaya Meningkatkan Hasil Belajar ...

\section{DAFTAR RUJUKAN}

Ahmad, Djauzak. 1996. Pedoman

Pelaksanaan PBM di SD.

Jakarta: Depdikbud.

Adnan, Warsito. 2003. PKn. Solo:

Tiga Serangkai Pustaka Mandiri

Depdikbud. 1994. Kurikulum

Pendidikan Dasar. Jakarta:

Depdikbud.

Djamariah, BS dan Azwan Zain.

1997. Startegi Belajar

Mengajar. Jakarta: PT Rineka

Cipta

Engkoswara. 1996. Pedoman

Penyusunan Karya Ilmiah

Untuk Angka Kredit Guru.

Bandung: Karangsewu

Moleong, Lexy J. 2002. Metodologi

Penelitian Kualitatif.

Bandung: Remaja Rosda Karya

Rusyan, Tabrani. 1992. Penuntun

Belajar Yang Sukses. Bandung:

Penerbit Nine Karya Jaya

Sri Wilujeung, Dyah, dkk. 1996.

Perangkat Pembelajaran PKn

SD. Jakarta: Tim Penatar PKn

Undang, Gunawan. 1998.

Peningkatan Mutu Proses

Belajar Mengajar Di Sekolah

Menengah. Bandung: Siger

Tengah 